\title{
The Paradox of Consumerism
}

\author{
Yana Dwi Christanti ${ }^{1}$, Vaisal Amir ${ }^{2}$, RB. Iwan Noor Suhasto ${ }^{3}$ \\ ${ }^{123}$ State Polytechnic of Madiun, Jalan Serayu No. 84 Madiun, East Java, Indonesia \\ \{yanadwic@pnm.ac.id\}
}

\begin{abstract}
This study aims to look at the culture of consumption in a postmodern society today, especially from a sharia (Islamic) perspective. Advances and developments in technology are also the focus of study in this study, this is because researchers also want to see the influence of technological progress and developments on the culture of consumption in postmodern societies. This study uses an interpretive research paradigm in which the study of transcendental phenomenology is the analytical tool. The subjects of this research are "accounting people", namely people who have been or are currently taking accounting studies, where they have received material related to accounting and finance. The results of this study indicate that technological developments greatly influence the culture of public consumption. Technology can have a very strong influence when combined with marketing techniques related to consumer finances which ultimately marginalize the rationality of most consumers even though they are aware of the marketing techniques used by startups that provide buying and selling services online. The results of this study also show that some consumers shop to fulfill their desires rather than their needs which are certainly not in accordance with Islamic teachings.
\end{abstract}

Keywords: Islam, Technology, Consumerism, Transcendental Phenomenology

\section{Introduction}

Changes in the consumption behavior of the Indonesian people from traditional to modern and then to a postmodern society marked by the regeneration of the productive age of Indonesians choosing to work in cities by following the trend of shopping using digital technology. A research shows that changes in the structure and shape of the economy will ultimately change the social and cultural conditions of the people in their surroundings, one of which is a change in people's consumption patterns from previously simple to more complex [1]. Traditional societies have consumption behavior that still pays attention to the humanist and spiritual side, while postmodern societies are more directed towards manipulating signs [2]. In the digital era like today, the dynamics of the economy change the consumption behavior of people who are affected by the effects of digitalization, especially those of the productive age who are pursuing higher education, who have understood and mastered the function of technology more than its main function. Not only that, digitalization also has an impact on changes in individual and community behavior in positive and negative forms [3].

The Islamic paradigm towards the advancement of science and technology has a different paradigm from the secular which says religion and science and technology are separate 
ontologically, epistemologically and axiologically, while the socialist paradigm denies the existence of religion and science and technology. Islam itself is a religion that is rational, flexible, and has the ability to face technological advances. Islamic teachings that are sourced from the Qur'an and Hadiths have legal flexibility in developing and understanding current issues. Islam is comprehensive and universal in terms of its laws, not only contains teachings about the relationship between humans and God in the form of worship, but also regulates the relationship between humans and humans which is called muamalah. The wider community usually calls the term muamalah the Islamic economy, which then regulates people's consumption as a whole and perfectly is mentioned in (Surah Al Israa: 29-39) which in essence humans are ordered by Allah SWT not to be too stingy and excessive in their consumption behavior.

This study uses transcendental religious phenomenology, because in this study the main focus investigated is individual awareness in shopping activities (consumption), so the transcendental phenomenology study is very in accordance with the objectives of this study. However, because the purpose of this study is to compare it with Islamic law, the researcher needs to include Islamic theory and law (sharia) in seeing the existing reality. This is because the use of transcendental phenomenology alone cannot provide solutions to changes in existing social realities, because the interpretive paradigm in this case transcendental phenomenology sees existing social realities as a form of order that does not need to be intervened to change [4].

The use of transcendental phenomenology and Islamic theory and law in this study implies the use of a qualitative research approach. This is because qualitative research is a humanistic research model, which places humans as the main object in social or cultural events. The qualitative paradigm sees social reality in various dimensions [5]. So that according to researchers, a qualitative approach is very suitable for this research. This research will be conditioned on the State Polytechnic of Madiun which has 8 Study Programs (Prodi) with a total of 1,039 students in the 2019/2020 school year. Even so, this study focuses on students who have or are currently studying accounting. This is because researchers want to see the extent to which the education and course materials, they receive can influence their consumption culture.

\section{Results and Discussions}

\subsection{Technology and Consumerism}

Indonesia is a large country, both in terms of population and area. This makes Indonesia a potential market for marketing products. This fact is further strengthened by various studies and analyzes related to Indonesia's economic growth, in which the consumption sector has an influence on economic growth by $60 \%$ (see: liputan6.com). The huge contribution of the consumption sector to economic growth encourages the author to conduct research, especially researchers from various backgrounds, ranging from religion, accounting and information technology. Although economics and technology are an intense part of the discussion in this study, the emphasis remains on the religious values that exist and their influence on the culture of people's consumption.

Economic growth that is supported by the consumption sector is a paradox for countries that want to achieve sustainable growth. Thus, economic growth from the consumption sector needs to be balanced with investment. From a religious perspective, the high level of 
consumption also needs to be investigated, whether this is reasonable and does not contradict the principles of sharia or actually violates religious norms that should be maintained. The various paradoxes of the consumption economy are increasingly finding momentum when information technology and telecommunications are developing rapidly accompanied by various information technology-based shopping platforms which are also growing rapidly and rapidly, while the birth of the Indonesian consumer society is marked by the mushrooming of centers. shopping such as shopping malls, leisure industry, fashion or fashion industry, beauty industry, culinary industry, advice industry, gossip industry, real estate, apartments, tourist areas, the establishment of expensive schools (with the 'plus' label), cell phones and invasion of lifestyles through the advertising and media industries.

These various platforms seem to be a haven for consumers who have limited time to visit outlets, kiosks, boutiques, and shopping centers which have been the places for them to devote all their shopping "desires", especially during a pandemic like today. This is as explained by all respondents, one of whom was Ms. Yuliana who explained that: "In times like this, people often spend time at home."

Ms. Yuliana's explanation strengthens the argument that information technology can encourage someone who is not busy to surf to see various kinds of products sold on online buying and selling platforms which ultimately helps them find the items they need or want. The online buying and selling platform, directly or indirectly, has generated consumptive interest in its users through the various facilities and attractive offers that are offered, as explained by Ms. Norafia when researchers interviewed related factors that motivated Ms. Norafia to shop in the marketplace. "Ease of transaction and also the promos given, even though the purchased goods are not necessarily needed."

Ms. Norafia's explanation shows that technology is very influential on a person's habits, even technology can change a person's lifestyle, especially fostering a consumptive nature in someone in the current materialist era, where they are supposed to "love" their property instead waste their wealth. There are a number of research results. empirical evidence that materialism is associated with a number of demographic and behavioral variables. "Blue collar" respondents (lowly employees) scored the highest on the materialism scale, while respondents from religious institutions had the lowest scores [6]. It was also found that the higher a person's score on the materialism scale (the more materialistic), the less happy he is in his life. The higher a person's score on the materialism scale, the lower the person's willingness to share what they have, both in the form of money and ownership (becoming stingier) [7]. This reluctance to give and share occurs in contributions to charitable and environmental organizations, as well as helping family and friends. Finally, most people describe materialistic people in negative and socially-undesirable terms [8].

This shift in the materialistic culture of modern society which "loves" its assets is certainly interesting to be investigated further, however, this research does not aim to see changes in the way people perceive their assets. This research is more aimed at looking at the influence of technology in fostering and encouraging the consumer's culture of society.

\subsection{Consumerism of "Accounting People"}

"Accounting People" is a term for respondents who have all been or are currently studying at the Accounting Department. The purpose and purpose of selecting respondents who have been or are currently taking courses in Accounting is to further see their rationality in addressing and using technology related to online shopping platforms. In interviews conducted by researchers related to the knowledge they had acquired during college with their rationality 
in shopping, an interesting thing was found. Six out of the seven respondents stated that they were aware of the discount "game" played by the sellers, but they still bought. Meanwhile, 1 respondent stated that he was aware of the discount "game" played by the sellers, but the respondent refused to buy (shop). This is as explained by Ms. Manda, a respondent who refuses to buy goods offered by a seller who applies the discount "game". "If I had a discount and found out that the real price was that much, I wouldn't buy it, sir. Unless I really need and are there, I will be forced to buy."

From Ms. Manda's statement, it can be concluded that Ms. Manda still uses her rationality in making shopping decisions. When the researcher further asked why Ms. Manda shopped, Ms. Manda explained that not all the items she bought were used for personal needs but also for resale. So from this an interesting conclusion can be drawn, namely the rationality of Ms. Manda is still more awake because Ms. Manda calculates profit and loss as the experience of Ms. Manda so far as a student who is also an entrepreneur. This is based on the researcher Manda's answer to the researcher's follow-up questions regarding the reasons for continuing to buy even though there is a discount "game" made by the seller. "Yes, I usually buy it because I don't have anyone selling the item anymore, or if I don't, even though the item I bought has a discounted "game", I can still make a profit, Sir from the sale I made, so I just bought it."

A different matter was expressed by Ms. Nimas, who so far had never experienced a discount "game" conducted by the sellers. According to Ms. Nimas' explanation, all this time Ms. Nimas has always been shopping at official stores where the price of goods is the same nationally and can be known by everyone. So, the discount price listed is actually a discount given by the seller. For information, Ms. Nimas likes to shop for cosmetics, where when there is a big discount from the seller, Ms. Nimas often buys goods that exceed her usual needs. "I always buy it at the official store, sir. So you know the real price, if the discount is what. Like during the current pandemic, the price was discounted 75\%, yes, 75\% ... Yes sir, if you know like that, I usually buy more items, so later when my cosmetics run out at least I still have supplies."

Ms. Nimas 'explanation shows that as a person who had studied at the Accounting Department, Ms. Nimas used Ms. Nimas' rationality to make shopping decisions at that time based on financial calculations. This means that Ms. Nimas continues to shop as much as Ms. Nimas' shopping habits. Ms. Nimas doesn't use the discount opportunity as the right time for Ms. Nimas to save money. So, from the interview, it can be concluded that, discounts that are indeed discounted do not fully make a person think of saving money (saving money to save). Shopping habits like that of Ms. Nimas and people who have the same views as Ms. Nimas are more on their perspective of seeing the future, where they think they can get a very cheap price which in the future is uncertain. they can get. Indirectly, they actually do not save (saving), because even though their future needs can already be met from purchasing discounted goods at this time, they will still use the money they have for shopping for future needs. This happens because in their minds the determining factor for buying goods is a discount, so if in the future the sellers continue to apply a discount strategy, of course they will buy the item. "To satisfy the desire because there are many discounts, so I am interested in shopping." (Ms. Nimas).

Based on the various explanations above, it can be concluded that the consumption culture practiced by the respondents is influenced by the discount, convenience, and various other attractive offers. In addition, a culture of consumption has also emerged as a result of the human response to the increase in their wealth. This is in line with research in which an interesting phenomenon was found in the research that the people of Wadung Village, located 
in Tuban Regency, who previously worked as farmers, switched professions to become factory workers. This in turn increases the consumption pattern of the people [1].

\subsection{Islamic Paradigm about Consumerism}

The definition of consumer behavior in Islam and consumer behavior in a conventional economy is actually not much different, in essence, the fulfilment of human needs, which distinguishes it from the point of view, in Islam the detailed objectives of consumer behavior are based on the rules of Islamic law, in contrast to the theory of consumption behavior in conventional economies which is based on the idea that consumption is the starting point and final goal of people's economic activities, while Islam teaches that consumption patterns must be rational, not irrational, which means that they are moderately moderate, not israf (excessive), tabzir and miser are contained in Surah Al Israa:29. Islam regulates human activities thoroughly and perfectly, including muamalah. Discussions related to muamalah in the Islamic economic system can be grouped into three major parts, namely siyasi or public sector, Tijari (private sector) and Ijtim'i (social welfare sector) [9]. Economic activity (tijari) includes three derivatives, namely production, consumption and investment. One of the economic activities discussed in economics is consumption and consumer behavior in meeting their needs.

Islam obliges its people to use the right basis and in accordance with the rules of Islamic law minhajul hayat. Specifically, the sources of Islamic economic law (including the legal basis for consumer behavior) are of 4 types; Al-Quran, sunnah, ijma', qiyas and ijtihad. These four bases are the basis for Muslims to behave and deliver them to safety. Meanwhile, Islamic orders regarding consumption are controlled by five principles, namely 1) Justice; 2) Cleanliness; 3) Simplicity; 4) Generosity; 5) morality [10]. Islam is a religion that is full of ethics, hat ethics in Islam can be grouped into 6 main axioms, namely: 1). Tauhid, 2). Justice, 3). Freedom of will and 4). Responsibility, lawful, and simple [3].

A person's attitude and behavior to buy goods or services is influenced by many factors, one of which is religion. According to Hirschman (Engel et al., 1990), consumers who increasingly identify with the religion they profess, the more likely it is to be affected. Religion lays the foundation for understanding and moral concepts in a person. The moral concept of religion greatly determines the belief system, so that often the moral teachings of religion are the sole determinant of attitudes. This is as explained by Ms. Nimas when the researcher asked about Ms. Nimas' considerations in buying cosmetics. "There must be a halal label and registered with MUI"

Diverse beliefs are an integral part of one's personality. This belief will monitor all his actions, words, and even feelings. When a person is attracted to something that seems pleasant, his faith will quickly act to weigh and examine whether this is permissible or not by his religion. Islam always ensures that consumptive attitudes, deliberate waste so that it exceeds boundaries and simple daily requirements are not carried out by its people. Islam also prohibits extravagance and living too much to follow worldly lusts, even though the enjoyment is obtained legally based on law. However, for most respondents this was often forgotten, especially if the existing platform was matched with various tantalizing promotions. "I am a consumptive person ... the reason to buy is because I want to buy." (Ms. Yuliana)

In relation to ethics (including the ethical-religious concept of israf and tabdzir) these two concepts are excessive behavior, for israf (extravagant) and tabdzir (or the term commonly used in society is mubadzir. In language, mubadzir refers to the perpetrator of tabdzir, namely people who did the tabdzir). Allah calls the perpetrator of tabdzir as his friend to Satan and 
Allah does not love those who like israf (extravagant). Allah Ta'ala said, "and do not spend wastefully.Indeed, the wasteful are brothers of the devils" (Surah Al-Israa:26-27). Allah also said, " And be not excessive. Indeed, He does not like those who commit excess." (Surah AlAn'am:141).

Ibn Abidin concluded that "Al-israf: using property for something that is right, but exceeds the justified limit. while tabdzir, uses property for something that is not true." [11]. For example; You overeat, that's israf. Meanwhile, if you use property for immorality, that's tabdzir.. Islam prohibits excessive grasping or excessive frugality. Where there is behavior that does not spend wealth to meet the necessities of life so that the harm is greater than the benefit, Allah explains in his words." And [they are] those who, when they spend, do so not excessively or sparingly but are ever, between that, [justly] moderate." (Surah Al-Furqan:67). Let someone who is able to provide a living according to his ability. And the person whose sustenance is reduced must provide a living from the wealth given to him by Allah. Allah does not bear burdens on someone but only what Allah has given him. "Allah will bring about, after hardship, ease." (Surah At-Thalaaq:7).

Islam teaches moderate or moderate consumption behavior so that the obligation to spend that property can provide benefits to society and increase welfare. Where the wheels of the economy can turn. Consumption in the process of buying and selling transactions is a concept of alms, the existence of a profit from the sale and purchase transaction indirectly constitutes alms that does not hurt the recipient.

\section{Conclusion}

Islam views consumption with a moderate perspective, meaning that we are allowed to buy goods according to our needs. However, Islam also regulates that we do not buy things that have no benefit for us or in other words Islam prohibits us from being extravagant. Based on the research that has been done by researchers, it can be concluded that the development of information technology combined with good promotional management can actually influence consumers to be consumptive, even for some respondents, various promos in the marketplace encourage them to always shop not because they need it. , but because they want the item. This is certainly contrary to Islamic teachings which encourage people to consume the things they need and should not be extravagant.

\section{References}

[1] F. Rahman and M. A. Affandi, "Perubahan Pola Perilaku Sosial Dan Ekonomi Buruh Tani Akibat Industrialisasi," J. Paradig., vol. 2, no. 1, 2014.

[2] J. P. Baudrillard, Masyarakat Konsumsi. Bantul: Kreasi Wacana, 2011.

[3] M. Ngafifi, "Kemajuan Teknologi Dan Pola Hidup Manusia Dalam Perspektif Sosial Budaya," J. Pembang. Pendidik. Fondasi dan Apl., vol. 2, no. 1, 2014.

[4] A. Kamayanti, Metodologi Penelitian Kualitatif: Pengantar Religiousitas Keilmuan. Jakarta: Yayasan Rumah Peneleh, 2017.

[5] N. Indriantoro and B. Supomo, Metodologi Penelitian Bisnis: Untuk Akuntansi dan Manajemen. Yogyakarta: BPFE Yogyakarta, 2002.

[6] R. W. Belk, "Materialism: Trait Aspects of Living in the Material World," J. Consum. Res., vol. 12, no. 3, pp. 265-280, 1985. 
[7] M. L. Richins and S. Dawson, "A Consumer Values Orientation for Materialism and Its Measurement," J. Consum. Res., vol. 19, no. 3, pp. 303-316, 1992.

[8] S. Founier and M. Richins, "Some theoretical and popular notions concerning materialism," J. Soc. Behav. Pers., vol. 6, no. 6, p. 403, 1991.

[9] M. S. Antonio, Bank syariah dari Teorik Praktek. Jakarta: Gema Insani Press, 2001.

[10] Mannan, Teori dan Praktek Ekonomi Islam. Yogyakarta: Dana Bhakti Wakaf, 1995.

[11] I. Abidin, Hasyiyah Radd Al-Mukhtar. Cairo: Musthafa al-Babi al-Halabi, 1966. 